\title{
Review on Effects of Land Use Land Cover Change on Plant Species Composition, The Case of Ethiopia
}

\author{
Sisay Taye Gifawesen \\ Department of Natural Resource Management (Forest and Nature Management), Jimma University, Jimma \\ University College of Agriculture and Veterinary Medicine, P. O. Box: 307 Jimma University, Ethiopia
}

\begin{abstract}
Summary
Land use is the purpose to which land is put by humans (protected areas, forestry for timber products, plantations, row-crop agriculture, pastures, or human settlements). Land cover is the ecological state and physical appearance of the land surface (closed forests, open forests, grasslands). Land use change is when the use of a particular land is changed from one to another over time, (from natural vegetation (forest) to cultivation; cultivation to grazing or from swamp to cultivation). Ethiopia has the fifth largest floral diversity in tropical Africa. Between; 6,000-7,000 species of higher plants are estimated to exist in the country of which about 780-840 (12-13\%) plant species are estimated to be endemic. Ethiopia is one of the most populous countries in Africa, which is experiencing huge land use land cover (LULC) dynamics from natural vegetation to farming practices and human settlement. Existing sources indicate that about $40 \%$ of the country's land area was covered with dense forests at the turn of the 20th century. However, the forest coverage has reached a low level of 3.56\%. Agricultural expansion is, by far, the leading land-use change associated with nearly all deforestation cases $(96 \%)$ while energy consumption, infrastructure development involves both settlement expansion as well as the expansion of transport networks were also the major factor driving land use land cover change and resulting in Ethiopian plant species biodiversity loss. So that, estimation of land use impacts on biodiversity, especially at landscape scale, is necessary to ensure systematic conservation planning and designing sound land use management system.
\end{abstract}

Keywords: Land use, Land cover, Plant species diversity, Biodiversity

DOI: $10.7176 / \mathrm{JBAH} / 9-3-05$

\section{INTRODUCTION}

Land use is the purpose to which land is put by humans (e.g., protected areas, forestry for timber products, plantations, row-crop agriculture, pastures, or human settlements). Land cover is the ecological state and physical appearance of the land surface (e.g., closed forests, open forests, grasslands) (ESA, 2000). Land use represents the human use of the land (for example, small-scale agriculture, grazing, wildlife reserves or industrial zones). Land cover represents the biophysical cover (for example, Savannah, broad leaf forest, tea or built up areas) (Maitima et al., 2004). Land use change is when the use of a particular land is changed from one to another over time, (e.g., from natural vegetation/ forest to cultivation; cultivation to grazing or from swamp to cultivation) (Maitima et al., 2004).

The largest sources of change on the earth's surface are caused by human transformation of ecosystems and land systems. It has been recognized that changes in land use are important drivers of environmental change on spatial and temporal scales (Turner et al., 1994). The major consequences of these land use changes are reflected on the status of natural resources such as soil and water quality, global climatic system and biodiversity (Maitima et al., 2009). In most parts of the world, major changes largely involve transformation of forests to agricultural and settlement land as cited in (Eyayu and Heluf, 2010). The amount, rate and intensity of land use/cover changes are particularly considerable in developing countries (Rao and Pant, 2001). The study from Maitima et al., (2009) pointed out that, land use changes in East Africa have transformed land cover to farmlands, grazing lands, human settlements and urban centers at the expense of natural vegetation. These changes are associated with deforestation, biodiversity loss and land degradation.

Land cover change has an increasing impact on forest ecosystem worldwide. Zhi-yun et al., (1999) stated that the destruction of native habitats is recognized as one of the greatest threats to biological diversity. In Ethiopia, change in land use mainly through the conversion of natural forests to agricultural land and settlement is the most widely distributed activity. Existing sources indicate that about $40 \%$ of the country's land area was covered with dense forests at the turn of the 20th century (Breitenbach, 1961). Reports from WBISPP (2004) shown that the presence of old remnant forests around old churches and protected areas are indicators of the types of forests which covered the country in the past. However, the forest coverage has reached a low level of $3.56 \%$

Human land use may detrimentally affect biodiversity, yet long-term stability of species communities is vital for maintaining ecosystem functioning. Community stability can be achieved by higher species diversity (portfolio effect), higher asynchrony across species (insurance hypothesis) and higher abundance of populations (Blüthgen et al., 2016). The long-term functional stability of ecosystems is driven by the stability of species' populations and communities that contribute to ecosystem functions. Community stability thus represents a main goal for biodiversity conservation and sustainable management of natural resources (Blüthgen et al., 2016). Gradual 
increases in land use intensity indirectly affected stability through changes in asynchrony, diversity and abundance (Blüthgen et al., 2016). So that, estimation of land use impacts on biodiversity, especially at landscape scale, is necessary to ensure systematic conservation planning (Hackman, 2015). Hence, the objective of this review paper is to overview the information regarding effects of land use land cover change on plant species diversity as it ensure systematic conservation planning and designing sound land use management system.

\section{Land Use and Land Cover Dynamics and Links}

For centuries, humans have been altering the earth's surface to produce food through agricultural activities. Nearly one third of earth's land surface is composed of croplands and pastures and over half of the cultivated areas have been cleared in the last century (Houghton 1994). In the last few decades, conversion of grassland, woodland and forest into cropland and pasture has risen dramatically in the tropics (Houghton, 1994). Global forest biodiversity is changing at an unprecedented rate; and the most important drivers are land conversion, climate change, pollution, unsustainable harvesting of natural resources and the introduction of exotic species (EPCC, 2015). This acceleration has spurred renewed concerns about the role of land use change in driving losses in biological diversity, soils and their fertility, water quality and air quality. Also, land use activities are calculated to contribute from 20$75 \%$ of all atmospheric emissions of important greenhouse gases (Reid et al., 2000). West African Savanna ecosystems are undergoing severe changes in their vegetation composition due to the impact of human land use and changes in climatic conditions (Zerbo et al., 2016).

Figure 1: Conceptual linkages among land use, land degradation (represented by soils and biological productivity), biodiversity and human values

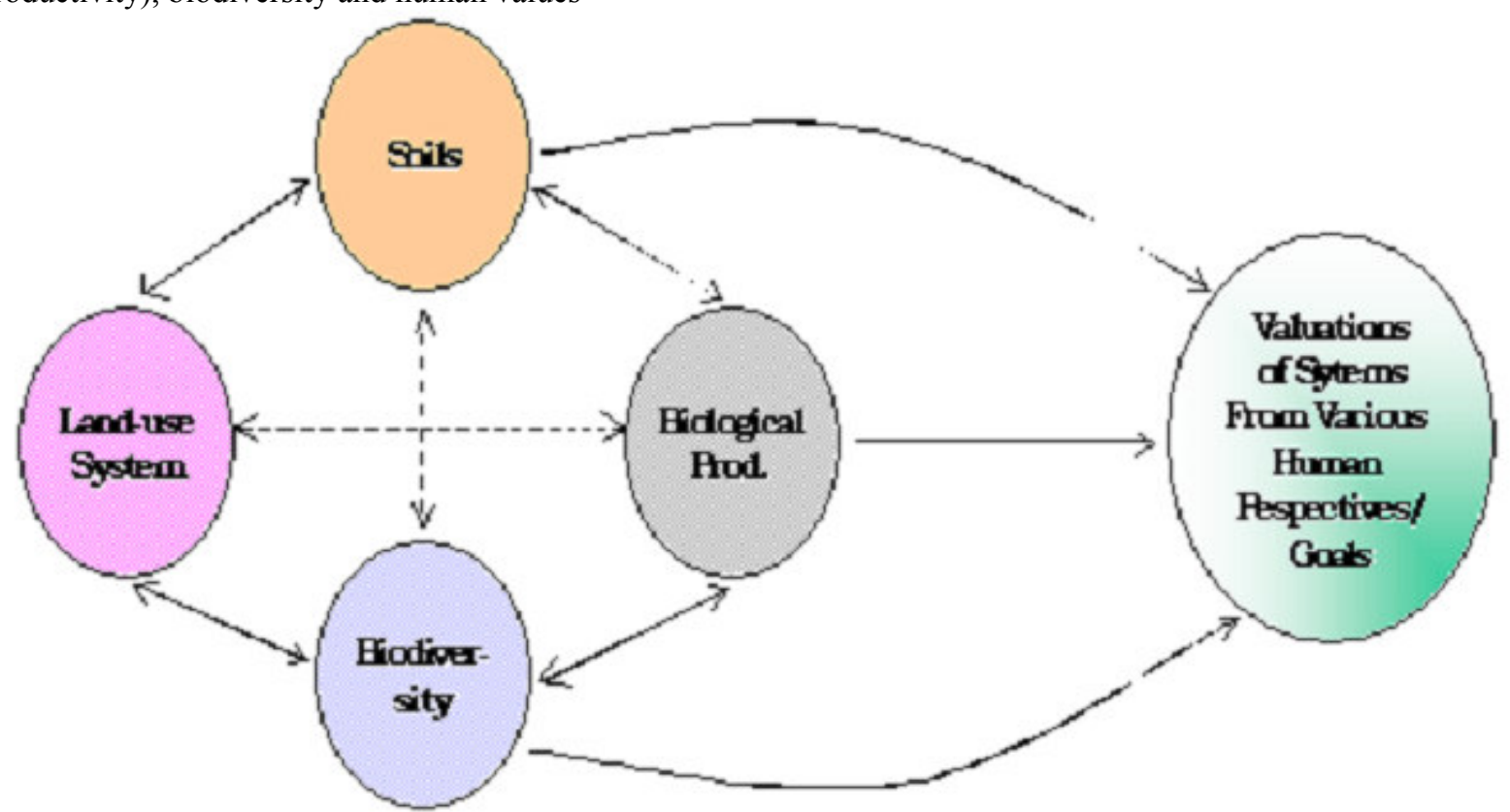

Source: (Maitima and Olson, 2001) 
Figure 2: Schematic representation of land use sequences in East Africa.

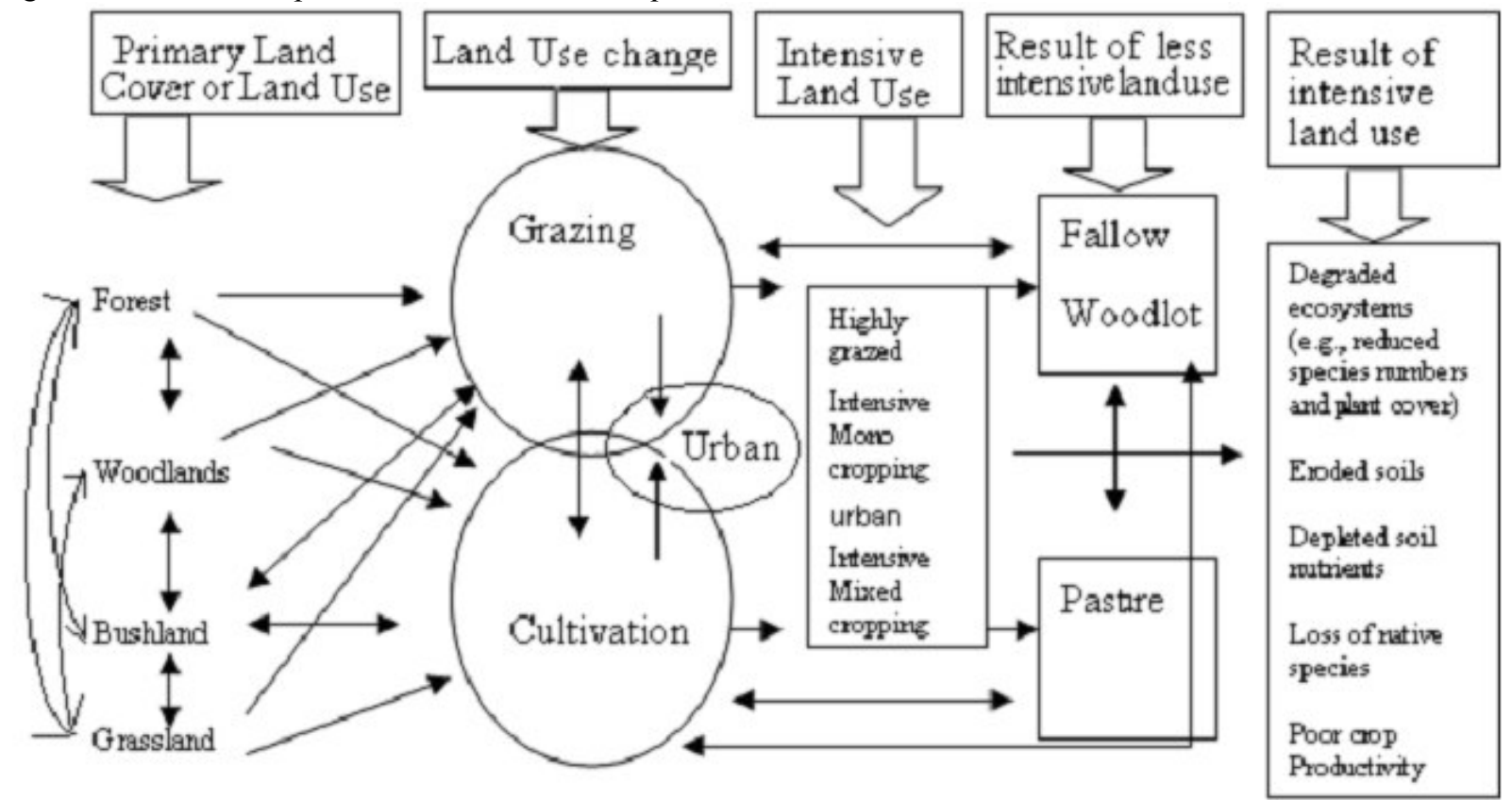

Source: (Maitima et al., 2004)

Worldwide changes to forests, farmlands, waterways, and air are being driven by the need to provide food, fiber, water, and shelter to more than six billion people. Global croplands, pastures, plantations, and urban areas have expanded in recent decades, accompanied by large increases in energy, water, and fertilizer consumption, along with considerable losses of biodiversity. Such changes in land use have enabled humans to appropriate an increasing share of the planet's resources, but they also potentially undermine the capacity of ecosystems to sustain food production, maintain freshwater and forest resources, regulate climate and air quality, and ameliorate infectious diseases. We face the challenge of managing trade-offs between immediate human needs and maintaining the capacity of the biosphere to provide goods and services in the long term (Foley et al., 2009).

Growth in human population around natural forests, the demand for more agricultural land and increase in land use activities have exerted pressure on topical forests whose tree cover, species composition and structure have changed over the past few decades. According to Godfrew et al., (2010), there is strong relationship between land use and land cover change. Understanding this relationship necessitates documentation of pasts and current alterations in land cover. Recent projected land use trends in the tropics indicate that land use activities are causing rapid change in natural forest composition and structure (Godfrew et al., 2010). Extensive uncontrolled and unplanned land use accelerates forest fragmentation and results in substantial loss of forest cover and biomass. Such biomass losses from fragmented forests have been found to be a significant source of greenhouse emissions (Godfrew et al., 2010). The effects of these changes on terrestrial biodiversity and ecosystem processes are of great concern (Dale et al., 2009). Land use has generally been considered a local environmental issue, but it is becoming a force of global importance.

\subsection{Land Use Land Cover Dynamics in Ethiopia}

Ethiopia with an area of $1,130,000 \mathrm{~km}^{2}$ is one of the most populous countries in Africa, which is experiencing huge LULC dynamics from natural vegetation to farming practices and human settlement (Kidanu, 2004). The Ethiopian highlands are subjected to important land degradation as a result of land use and land cover changes during the second half of the 20th century (Tesfaye et al., 2014). The problem of land cover dynamics is more severe in the highlands, which account nearly $44 \%$ of the country's landmass and have been cultivated for millennia (Eshetu and Hogberg, 2000). Inappropriate agricultural practices, and high human and livestock population pressure have been the main facilitators for the land degradation processes such as biodiversity loss, deforestation, soil erosion and soil quality in the highlands (Alemu, 2015). Following the pressure on natural resources, the land use and land cover types are changing so rapidly. Around 19th century, about $40 \%$ of the land mass of Ethiopia was under forest cover but this figure had gone below 3\% before two decades (EFAP, 1994).

According to Tadesse (2001) reports, land use in Ethiopia is categorized as $12 \%$ arable land, $1 \%$ permanent crops, $40 \%$ permanent pastures, $25 \%$ forest and woodland, and $22 \%$ other. These shows environmental issues facing the country include deforestation, overgrazing, soil erosion, and desertification (Muluneh, 2010). To overcome such issues like other parts of the world, the use and management of natural resources, and returning the vast degraded landscapes to protective and/or productive systems, have substantial importance to attain the 
goal of sustainable development in Ethiopia (Lemenih and Teketey, 2004). This, in turn, requires an understanding of the dynamics in time and space of these resources. In this regard, the importance of spatial data monitoring and evaluation for proper management of natural resources is critical. Some studies have been conducted to estimate and monitor LULC changes in different parts of the Ethiopian highlands (Abate, 1994). These reports have shown heterogeneity in direction, pattern, type, and/or magnitude of LULC changes in the country. For instance, Zeleke and Hurni (2001) reported a sharp decrease of forest cover while Bewket (2002) found the opposite, i.e., an increasing trend. In terms of magnitude for changes, Zeleke and Hurni (2001) reported an increase in cultivated lands by $38 \%$ in 38 years (1957-1995) and results for a disappearance of 27\% natural forest cover from 1957 1997 in the North-western Ethiopian highlands. On the other hand, Tegene (2002) reported an increase in croplands only by $5.5 \%$ in 43 years (1957-2000). Results of various studies have demonstrated the need for a study focusing on location specific LULC dynamics for sustainable management and decision-making processes related to the use and conservation of natural resources (Lunetta et al., 2006).

Figure 3: Ethiopian Land-uses replacing forest over the period 2000-2013 (as \% of the total forest loss over this period)

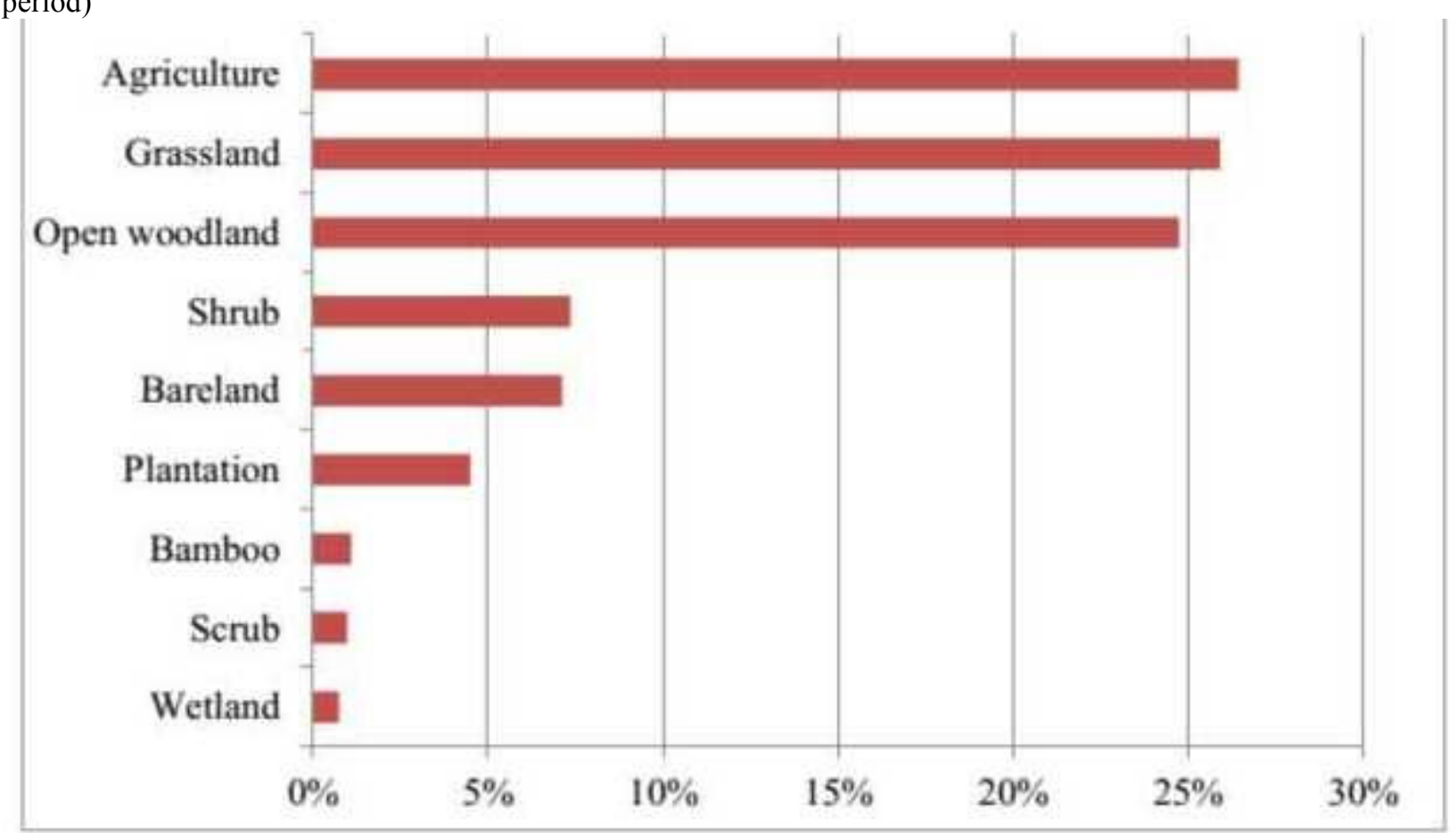

Source: (UNFCCC, 2016)

\subsection{Biodiversity in Ethiopia}

Biodiversity is the variability among living organisms from all sources including, inter alia, terrestrial, marine and other aquatic ecosystems and the ecological complexes of which they are part, this includes diversity within species, between species and of ecosystems (CBD, 1992) as cited in (IBC, 2005). In short, biodiversity refers to the variety of life on earth. This variety provides the building blocks to adapt to changing environmental conditions in the future. The Convention on Biological Diversity (CBD) is an international environmental agreement established for the conservation, sustainable use, and fair and equitable sharing of benefits of biological resources. Convention on Biological Diversity (CBD) is the first global agreement aimed on conservation and sustainable use of biological diversity (Secretariat of the Convention on Biological Diversity 2000 cited by (Chandra and Idrisova, 2011). It was negotiated in response to the global concerns on biodiversity loss, and entered into force in December 1993.

Ethiopia is endowed with diverse vegetation types ranging from high altitude Afro alpine vegetation in the central highlands to arid lowlands in the East, and afforest in the West. The country has the fifth largest flora in Africa and tremendous floristic diversity, with an estimated 6,500-7,000 species of higher plants of which about 12\% are endemic (Gebre-Egziabher 1991; Vivero et al., 2006) as cited in (Kebede et al., 2013).

Globally, the value of biodiversity as a key component of the environment and as a critical factor for socioeconomic growth and development (Maxted et al., 2015). Biodiversity provides free of charge services worth hundreds of billions of Ethiopian Birr every year that are crucial to the wellbeing of Ethiopia's society (IBC, 2005). It provides flexibility and options for our current (and future) use of natural resources. Almost $85 \%$ of the population in Ethiopia lives in rural areas, and a large part of this population depend directly or indirectly on 
natural resources (IBC, 2005) and Ethiopia's development in the future will continue to depend on the foundation provided by living resources and conserving biodiversity (IBC, 2005). Losing biodiversity is like losing the life support systems that we, and other species, so desperately depend upon. Therefore, conservation of biodiversity is fundamental to achieving sustainable development. Conservation of biodiversity is crucial to the sustainability of sectors as diverse as energy, agriculture, forestry, fisheries, wildlife, industry, health, tourism, commerce, irrigation and power.

\subsection{Natural forest Ecosystems in Ethiopia}

Ethiopia has the fifth largest floral diversity in tropical Africa (Motuma et al., 2010). Due to its diverse topography that has given rise to the development of wide diversities of flora and fauna rich with endemic elements. Between; 6,000-7,000 species of higher plants are estimated to exist in the country of which about 780-840 (12-13\%) plant species are estimated to be endemic (Teketay, 2001). However, the attention given to the conservation and sustainable use of these biological resources has been inadequate (IBC, 2005) and these biologically rich resources of Ethiopia are vanishing at an alarming rate due to extensive deforestation. Although several factors drive natural forest destruction in Ethiopia, agricultural land expansion triggered by increasing human population is probably the dominant force as cited in (Gebrehiwot \& Hundera, 2014). Under-valuation of environmental resources due to low-level of awareness about the role of ecosystems and the rate at which it is being deteriorated or lost and poor regard to the conservation problems have also contributed to under-investment in biological resources management (IBC, 2005).

\subsection{Land use Land Cover change driving forces and its Effect on Plant biodiversity of Ethiopia}

Land-use change has been reported to have one of the largest global impacts on biodiversity (Chapin et al., 2000). Loss of biodiversity is one of the most severe threats to sustainability, and land use and land use changes are still the single most important factor (Michelsen \& Lindner, 2015). Expansion of cultivation in many parts of East Africa has changed land cover to more agro-ecosystems and less cover of natural vegetation. The forest land's conversion into tree crops plantations plays a major role in the loss of biodiversity. These changes in LULC can also affect biological diversity, contribute to forest fragmentation, and lead to soil erosion, alter ecosystem services, disrupt socio-cultural practices, and increase natural disasters, such as flooding. The type and intensity of land use change will influence the number of species occurring in different habitats (Odiwe et al., 2012). Therefore, understanding the impacts of land-use change on species diversity is very critical for ecosystem functioning and stability (Odiwe et al., 2012) and calls for global attention for continuous monitoring of the changes (Kindu et al., 2013).

Ethiopia is experiencing huge LULC and loss of biodiversity is related to a range of biophysical and socioeconomic drivers (Kidanu, 2004). Land use and land cover (LULC) change through inappropriate agricultural practices and high human and livestock population pressure have led to severe land degradation in the Ethiopian highlands (Tesfaye et al., 2014). This has led to further degradation such as biodiversity loss, deforestation, and soil erosion (Tesfaye et al., 2014).

The major human impacts on biodiversity to date are probably through land use changes and habitat loss (Oliver and Morecroft, 2014). These are human activities or immediate actions that directly impact forest cover and loss of carbon (Lemenih et al., 2008). Changes in landscape due to such activities as agriculture, urban sprawl, unsustainable fuel wood consumption and transportation infrastructure are generally recognized as main direct drivers of deforestation and forest degradation resulting in the loss of biodiversity (Slingenberg et al., 2009). 
Figure 4: Processes of human impacts that lead to biodiversity loss

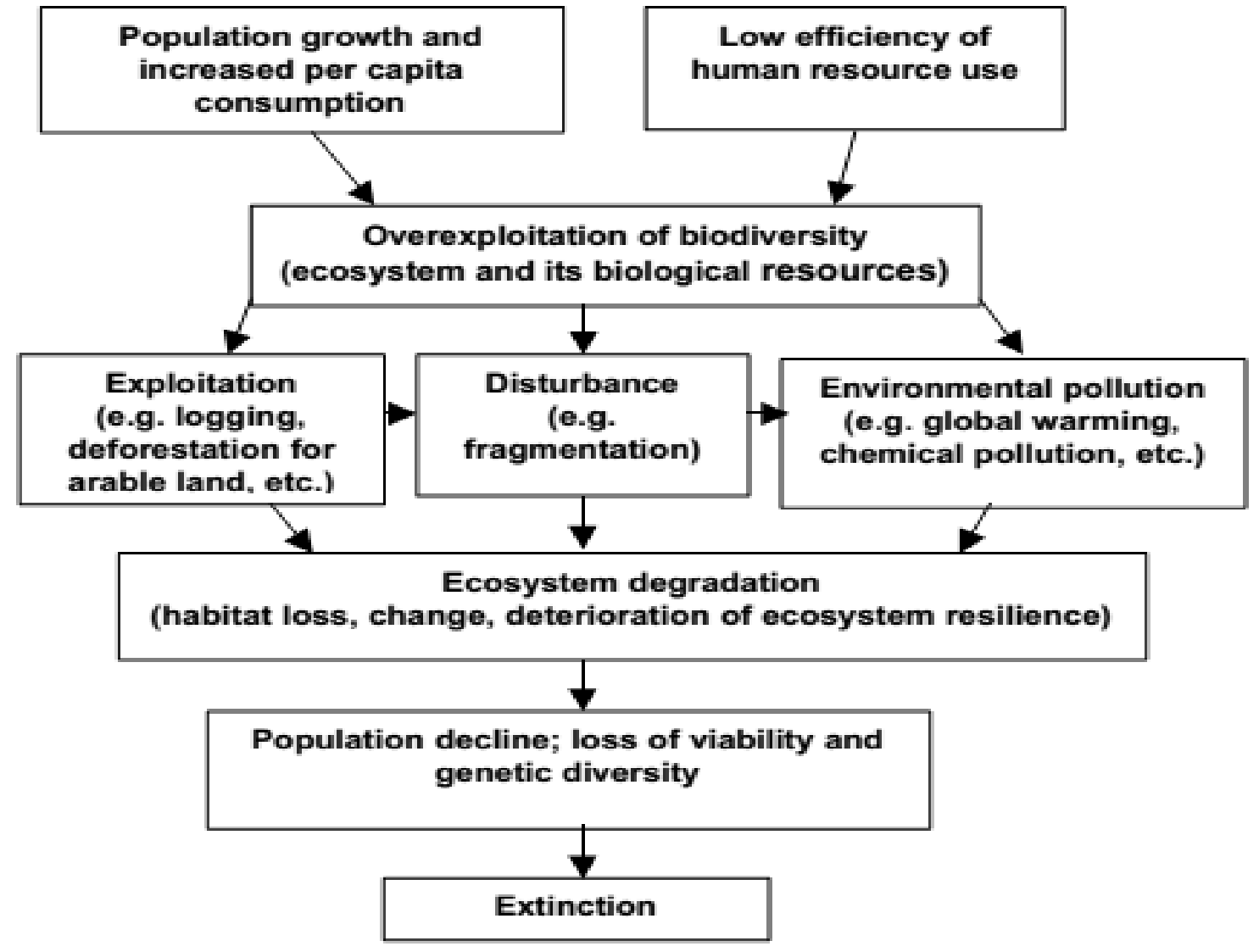

Source: (Kumar, 1999)

\subsubsection{Agricultural Expansion}

Agricultural expansion is, by far, the leading land-use change associated with nearly all deforestation cases (96\%). It includes, with more or less equal frequencies, forest conversion for permanent cropping, cattle ranching, shifting cultivation, and colonization agriculture (Slingenberg et al., 2009). Agricultural expansion is the most important proximate cause of land use change globally, followed by infrastructure development and deforestation (Slingenberg et al., 2009). Global population growth which has pressures for increased food as well as fuel production has been one of the primary drivers to convert nature into land for agricultural use. As reported by Alemu (2015), agricultural and economic growth in Ethiopia is constrained by the deteriorating natural resource base, especially in the highlands where $80 \%$ of the population lives. Conversion of forests to agricultural land is the most prominent deforestation driver, as agriculture is more attractive than forestry (Tadesse et al., 2008).

Forest land conversion has caused deforestation that leads loss of plant species diversity and also results for the emission of an estimated 40 mega tones of CO2 from deforestation in 2010 (MOA, 2013). Despite policy efforts on reducing deforestation, around 13 million hectares of forests continue to be lost annually. To assess the types and severity of biodiversity impacts this level of deforestation has on biodiversity, it is important to differentiate between the highest deforestation rate (in \%) and the highest overall annual losses of forest (per hectares)(Slingenberg et al., 2009). According to WBISPP (2004), 80\% of new agricultural land developed between 2000 and 2008 was converted from forests, woodlands or shrub lands (EPCC, 2015).

The implications of these changes suggest that the land use/cover changes have skewed to the rampant conversion of areas once covered with vegetation to cultivation without adequate use of soil and water conservation and rehabilitation practices (Alemu, 2015). Traditionally, land use in Ethiopia was exclusively limited to primitive field cropping and extensive cattle grazing expanding to forests (Lemenih et al., 2008). The expansion of the two land uses was due to the fact that forests were considered as free virgin land that had highly productive soils for cultivation of cash crops and sedentary agriculture (Breitenbach and Koukol, 1962). As in most developing countries, the major cause of vegetation change in Ethiopia is related to activities of cultivation agriculture (Sherefa, 2006). According to Sherefa (2006), from 1973 to 2000, agriculture alone was the driving force for 83.4\% and $70.1 \%$ of the natural vegetation loss in ASLNP and in Zeway Awassa Basin respectively. The strong influence of agriculture in a National Park is unfortunate and concerning. However, the drive to expand has been largely set off by the need to fulfill household food demand. Only $13.3 \%$ of the farmers expanded their agriculture to produce 
cereals for commercial purpose (Sherefa, 2006).

Figure 5: Deforestation rates in Ethiopia between 1973 and 1990

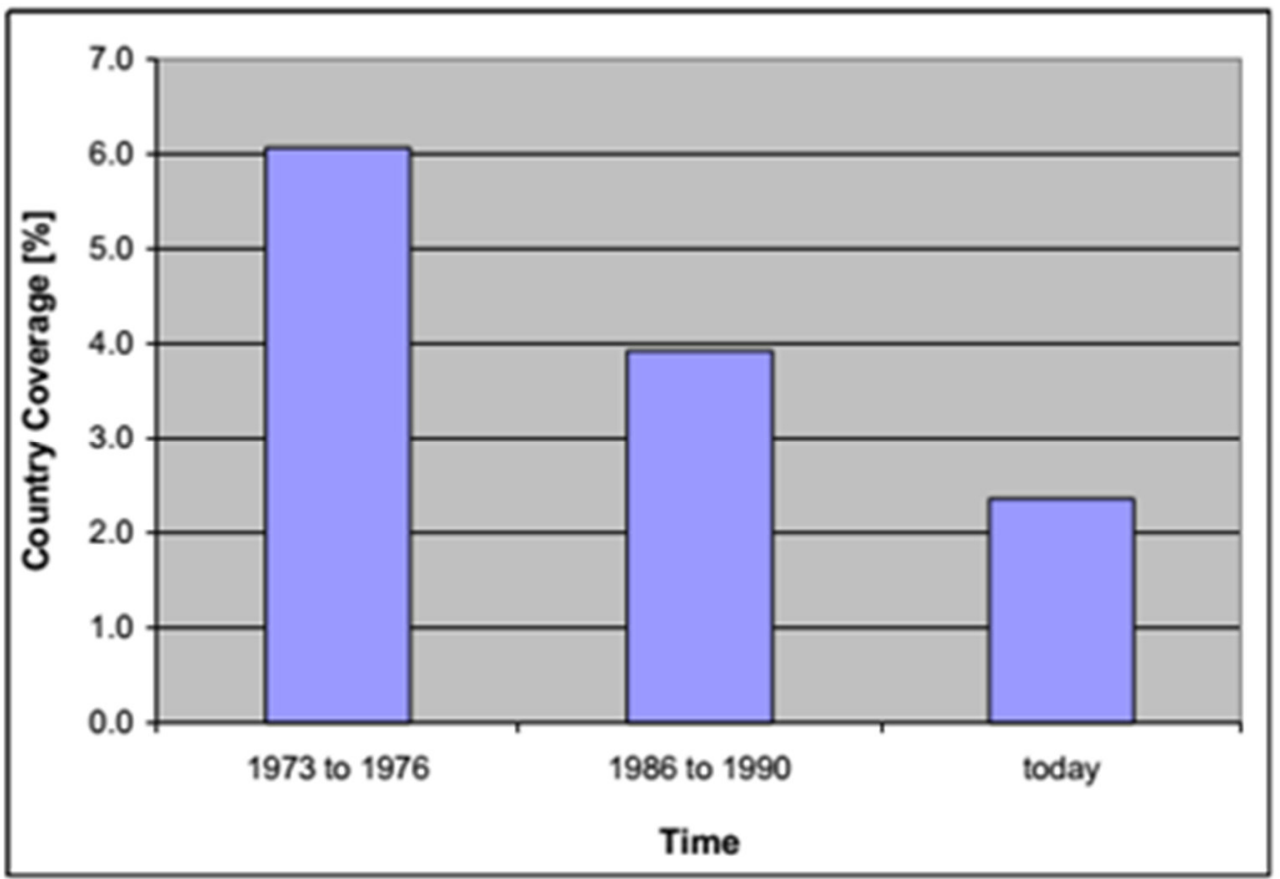

\subsubsection{Unsustainable fuel wood consumption}

Source: (Reusing, 2000)

The second most prominent driver, with most of its impact focused on forest degradation, is unsustainable fuel wood consumption. Ethiopia's energy consumption is predominately based on biomass energy sources (94\%). The biomass energy sources include traditional energy sources such as fuel wood, charcoal, branches, leaves and twigs. The current needs largely exceed the level of sustainable production (e.g. from dead wood and plantations), leading to massive degradations of the biomass (WBISPP, 2004). Between 2000 and 2010, degradation due to fuel wood consumption claimed an estimated 135 million tons of woody biomass from the total woody biomass existing in 2000 (MOA, 2013). This dependence of large segment of people on biomass fuel for energy source has contributed to the degradation of vegetation of different developing countries like Ethiopia (EFAP, 1994).

\subsubsection{Infrastructure development}

Infrastructure development involves both settlement expansion as well as the expansion of transport networks (Slingenberg et al., 2009). Urban sprawl for example affects land change elsewhere through the transformation of urban-rural linkages (Slingenberg et al., 2009). Land cover (vegetation cover), land use change and deforestation were highly interrelated and interdependent on one over another and thus influencing the environment (Shombe, 2015). Resettlement was the influential factor for land use and land cover changes. Deforestation as a result of resettlement a deriving factor for the land use and land cover changes. Biodiversity in general could be affected a result of removal of vegetation of the woodland due to settlement expansion. Therefore, the species of flora and fauna found in the woodland ecosystem could be subjected to threat and eventually extinction because of the increased pressure from the resettlement scheme. A report from (Shombe, 2015) depicts that the vegetation cover of Chewaka resettlement site has been reduced considerably by 42.4 percent $\%$ due to different human activities. This may lead to removal of plant species causing loss of vegetation and loss of productivity. 
Figure 6: Detailed images of Biodiversity Losses (Causes of the loss of biodiversity)

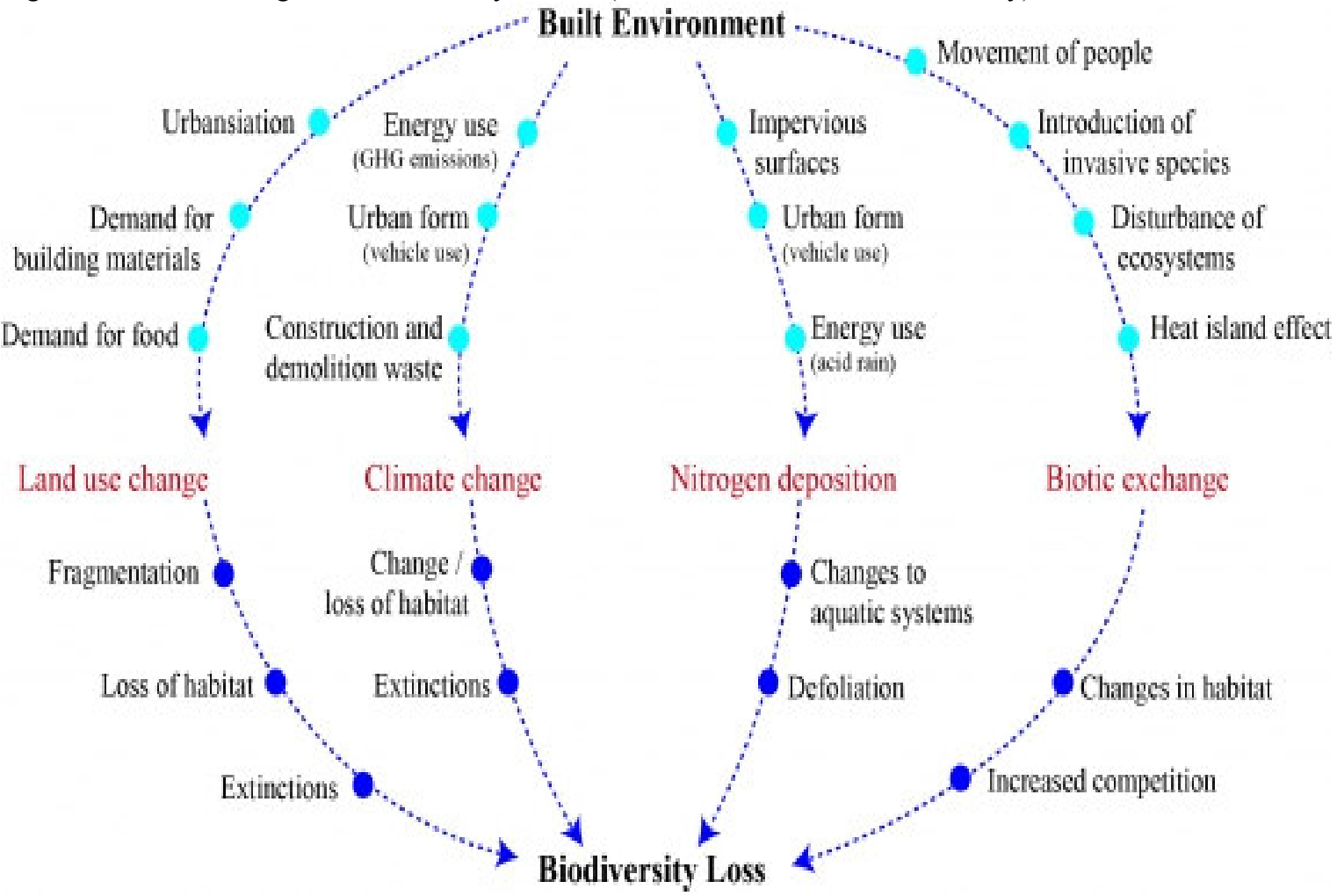

Source: Available on:-http://www.eniscuola.net/en/argomento/biodiversity1/loss-of-biodiversity/causes-of-theloss-of-biodiversity/).

\section{CONCLUSION AND RECOMMENDATIONS}

Loss of biodiversity is associated with land use/land cover changes that are related to a range of biophysical and social-economic drivers. Generally, land cover changes had tremendously reduced plant diversity and land use change is the main driving forces for species biodiversity loss in Ethiopia. The primary natural forests of Ethiopia are reduced remarkably both in species richness and diversity after logging and regeneration. Under multiple harvests and continues cultivation, much of natural forests are lower. Transforming primary forests and shrubs to commercial forest will destroy habitats for some plant species. The implications of these changes suggest that the land use/cover changes have skewed to the rampant conversion of areas once covered with vegetation to cultivation without adequate use of soil and water conservation and rehabilitation practices. Thus, Community stability represents a main goal for biodiversity conservation and sustainable management of natural resources. The forest land's conversion into other land uses plays a major role in the loss of plant biodiversity. Therefore, improving the understanding of land use and land cover dynamics and its driving forces and its impacts on species diversity can help in projecting future changes in land use and land cover and to instigate more appropriate policy interventions for achieving better land management. Thus proper management and monitoring practices is required. Hence the following recommendations are forwarded.

$>$ Continuous forest inventory will be conducted to identify land use practices and woody plant species in protected areas

$>$ Planning and management of the forest should be assisted by research findings, such as detailed ecological studies in relation to various environmental factors such as soil type and properties to promote the sustainable use of the forest and its products. This, in turn, requires an understanding of the dynamics in time and space of these resources. In this regard, the importance of spatial data monitoring and evaluation for proper management of natural resources is critical.

$>$ Comprehensive studies should be initiated to document the plant resource utilization pattern

$>$ The introduction of conservation measures like afforestation and reforestation program, will be important as plantation enhance more sustainable ecosystem which will ultimately address and protect vegetation's, contributes to biodiversity, soil and water conservation, and more recently for carbon sequestration, and wood production and reduces burdens from natural forests so as to reduce loss of natural plant species biodiversity. 


\section{REFERENCES}

Abate, S., 1994. Land use dynamics, soil degradation and potential for sustainable use in Metu area, Illubabor region, Ethiopia.

Alemu, B., 2015. The Effect of Land Use Land Cover Change on Land Degradation in the Highlands of Ethiopia. , J Env Earth Sci 5(1), pp.1-13.

Chandra, A. and Idrisova, A., 2011. Convention on Biological Diversity: a review of national challenges and opportunities for implementation. Biodiversity and Conservation, 20(14), pp.3295-3316.

Bewket, W., 2002. Land cover dynamics since the 1950s in Chemoga watershed, Blue Nile basin, Ethiopia. Mountain Research and Development, 22(3), pp.263-269.

Blüthgen, N., Simons, N.K., Jung, K., Prati, D., Renner, S.C., Boch, S., Fischer, M., Hölzel, N., Klaus, V.H., Kleinebecker, T. and Tschapka, M., 2016. Land use imperils plant and animal community stability through changes in asynchrony rather than diversity. Nature communications, 7, p.10697.

Von Breitenbach, F., 1961. Forests and woodlands of Ethiopia, a geo-botanical contribution to the knowledge of the principal plant communities of Ethiopia, with special regard to forestry. Ethiopian Forestry Review, 1, pp.5-16.

Dale, V.H., Lannom, K.O., Tharp, M.L., Hodges, D.G. and Fogel, J., 2009. Effects of climate change, land-use change, and invasive species on the ecology of the Cumberland forests. Canadian Journal of Forest Research, 39(2), pp.467-480.

Teketay, D., 2001. Vegetation types and forest fire management in Ethiopia.

EFAP (Ethiopian Forestry Action Program), 1994. Ethiopian Forestry Action Program, Vol. 2. The challenge for development. Ministry of Natural Resources Development and Environmental Protection, Addis Ababa.

EPCC, 2015. Biodiversity and Ecosystems.

ESA, 2000. Ecological Principles and Guidelines for Managing the Use of Land. Ecological Principles the Ecological Society of America's Committee on Land Use. Ecological applications, 10(3), pp.639-670.

Eshetu, Z. and Högberg, P., 2000. Reconstruction of Forest Site History in Ethiopian Highlands Based On 13C Natural Abundance of Soils. AMBIO: A Journal of the Human Environment, 29(2), pp.83-89.

Eyayu Molla, Heluf Gebrekidan, T.M. and M.A., 2010. Patterns Of Land Use/Cover Dynamics In The Mountain Landscape Of Tara Gedam And Adjacent Agro-Ecosystem, Northwest Ethiopia Eyayu Molla 1 , Heluf Gebrekidan 2 , Tekalign Mamo 3. , 33(2), pp.75-88.

Foley, Jonathan A, Jonathan A Foley, Ruth Defries, Gregory P Asner, Carol Barford, Gordon Bonan, Stephen R Carpenter et al., 2009. "Global Consequences of Land Use." 570 (2005).

Gebrehiwot, K. \& Hundera, K., 2014. Species composition, Plant Community structure and Natural regeneration status of Belete Moist Evergreen Montane Forest, Oromia Regional state, Southwestern. , 840(1), pp.97101.

Hackman, K.O., 2015. A method for assessing land-use impacts on biodiversity in a landscape. Global Ecology and Conservation, 3, pp.83-89. Available at: http://dx.doi.org/10.1016/j.gecco.2014.11.003.

Houghton, R.A., 1994. The Worldwide Extent of Land-Use Change. Bioscience, 44(5), pp.305-313.

IBC, 2005. Government of the Federal Democratic Republic of Ethiopia Institute, of Biodiversity Conservation National Biodiversity, (December).

Godfrew, A. J., Clement, A. O., Refaat, A. A. A., James, M. K., Susan B., Peter Ndemere, P.B. and J.O., 2010. The Impacts of Land Use and Forest Activities on Tree Species Composition and Structure on the Edge of Budongo Forest Reserve, Uganda.

Kebede, M., Yirdaw, E., Luukkanen, O. and Lemenih, M., 2013. Plant community analysis and effect of environmental factors on the diversity of woody species in the moist Afromontane forest of Wondo Genet, South Central Ethiopia. Biodiversity: Research and Conservation, 29, pp.63-80.

Kidanu, S., 2004. Using Eucalyptus for Soil and Water Conservation on the Highland Vertisols of Ethiopia. Ph.D. Thesis, Wageningen University and Research Centre, Wageningen, the Netherlands

Kindu, M., Schneider, T., Teketay, D., \& Knoke, T. (2013). Land Use / Land Cover Change Analysis Using Object-Based Classification Approach in Munessa-Shashemene Landscape of, 2411-2435.

Kumar, H. D. (ed.). 1999. Biodiversity and Sustainable Conservation. Science Publishers, Inc. USA

Lemenih, M., Toera, M., Karltun, E. (2008). Deforestation on: Impact on soil quality, biodiversity and livelihoods in the highlands of Ethiopia. In Deforestation on Research Progress, Sanchez, IB., Alonso, CL. (eds.), Pp. 21-39. Nova Science Publ.

Lemenih, M.; Teketay, D. Potentials of plantation forests in fostering the restoration of native flora and fauna at degraded sites in Ethiopia: A review. Ethiop. J. Biol. Soc. 2004, 3, 81-111.

Lunetta, R.S., Knight, J.F., Ediriwickrema, J., Lyon, J.G. and Worthy, L.D., 2006. Land-cover change detection using multi-temporal MODIS NDVI data. Remote sensing of environment, 105(2), pp.142-154.

Maitima, J.M., Mugatha, S.M., Reid, R.S., Gachimbi, L.N., Majule, A., Lyaruu, H., Pomery, D., Mathai, S. and Mugisha, S., 2009. The linkages between land use change, land degradation and biodiversity across East 
Africa. African Journal of Environmental Science and Technology, 3(10): 310-25.

Maitima JM, Olson JM (2001). Guide to Field Methods for Comparative Site Analysis for the Land Use Change, Impacts and Dynamics Project.www.lucideastafrica.org.

Maitima, J., Reid, R. S., Gachimbi, L. N., Majule, A., Lyaruu, H., Pomery, D., Mugisha, S. (2004). By Regional synthesis paper: A methodological guide on how identify trends in the linkages between changes in land use, biodiversity and land degradation by.

Maxted, N., Avagyan, A., Frese, L., Iriondo, J., Brehm, J. M., Singer, A., Iriondo, J. (2015). ECPGR Concept for in situ conservation of crop wild relatives in Europe ECPGR Concept for in situ conservation of crop wild relatives in Europe, (March).

Michelsen, O. \& Lindner, J.P., 2015. Why Include Impacts on Biodiversity from Land Use in LCIA and How to Select Useful Indicators, pp.6278-6302.

MOA (Ministry of Agriculture), (2013). Terms of Reference for Developing Capacities for a national Measuring, Monitoring, Reporting and Verification System to support REDD+ participation of Ethiopia, Background, Capacity Assessment and Roadmap. 37P.

Motuma Didita, Sileshi Nemomissa \& Tadesse Woldemariam. 2010. Floristic and structural analysis of the woodland vegetation around Dello Menna, Southeast Ethiopia. Journal of Forestry Research, 21: 395-408.

Muluneh, A., 2010. Synthesis of Research on Land Use and Land Cover., pp.1-39.

Odiwe, A.I., Olowoyo, J.O., and Ajiboye, O., 2012. Effects of Land-Use Change on Under Storey Species Composition and Distribution in a Tropical Rainforest. Notulae Scientia Biologicae, 4(1), p.150-156.

Oliver, T.H. \& Morecroft, M.D., 2014. Interactions between climate change and land use change on biodiversity : attribution problems, risks, and opportunities. , 5(June), pp.317-335.

Ouyang Zhi-yun, Wang Ru-song, Wang Xiao-ke, xiao H., 1999. Impacts of land cover change on plant and bied species diversity in Hainan Island, China. , p.199.

Rao, K.S. and Pant, H. (2001). Land use dynamics and landscape change pattern in a typical micro watershed in the middle elevation zone of central Himalaya, India. Agriculture, Ecosystem and Environment 86:113-123.

Reid, R.S., Kruska, R.L., Muthui, N., Taye, A., Wotton, S., Wilson, C.J. and Mulatu, W., 2000. Land-use and land-cover dynamics in response to changes in climatic, biological and socio-political forces: the case of southwestern Ethiopia. Landscape Ecology, 15(4), pp.339-355.

Reusing, M., 2000. Change detection of natural high forests in Ethiopia using remote sensing and GIS techniques. International archives of photogrammetry and remote sensing, 33(B7/3; PART 7), pp.1253-1258.

Sherefa, M.B., 2006. Remote Sensing \& GIS for Land Cover / Land Use Change Detection and Analysis in the Semi-Natural Ecosystems and Agriculture Landscapes of the Central Ethiopian Rift Valley.

Shombe Oshore, 2015. Impacts of Resettlement Schemes on Land Use and land Cover Changes, in Gumgumuta Settlement Village, in Boreda Woreda Gamo-Gofa Zone, Southern Regional State of Ethiopia.

Slingenberg, A., Braat, L., Van Der Windt, H., Rademaekers, K., Eichler, L. and Turner, K., 2009. Study on understanding the causes of biodiversity loss and the policy assessment framework 1-206.Report to the European Commission Directorate-General for Environment, ECORYS Research and Consultation, the Netherlands.

Tadesse, G. (2001). Land degradation: A challenge to Ethiopia. Environmental Management 27, 815-824

Tadesse, D., Woldemariam, T. Senbeta, F. (2008). Deforestation on of Afromontane rainforests in Ethiopia. In Deforestation on Research Progress, Sanchez, IB., Alonso, CL. (eds.), Pp. 19-39. Nova Science Publ.

Tegene, B. Land-cover/land-use changes in the derekolli catchment of the South Welo Zone of Amhara Region, Ethiopia. East. Afr. Soc. Sci. Res. Rev. 2002, 18, 1-20.

Tesfaye, S., Guyassa, E., Joseph Raj, A., Birhane, E. and Wondim, G.T., 2014. Land use and land cover change, and woody vegetation diversity in human driven landscape of Gilgel Tekeze Catchment, Northern Ethiopia. International Journal of Forestry Research.

Turner, B.L., Meyer, B. and Skole, D.L. (1994). Global land use/land cover: towards an integrated study. Ambio 23:91-95.

UNFCCC (2016). Ethiopia's Forest Resource Assessment Reference

Von Breitenbach, F., Koukol, J. (1962). Menagesha state forest: A description on of the forest, its management and its future development including the national park project. Ethiopian forestry review No. 3/4: 15-34.

WBISPP, 2004. Woody Biomass Inventory and Strategic Planning Project. Forest Resources of Ethiopia. Addis Ababa, Ethiopia. 118 pp.

Zeleke, G. and Hurni, H., 2001. Implications of land use and land cover dynamics for mountain resource degradation in the Northwestern Ethiopian highlands. Mountain research and development, 21(2), pp.184191.

Zerbo, I., Bernhardt-römermann, M., Ouédraogo, O., Hahn, K., \& Thiombiano, A. (2016). Effects of Climate and Land Use on Herbaceous Species Richness and Vegetation Composition in West African Savanna Ecosystems, 2016. 
Sala, O.E., Chapin, F.S., Armesto, J.J., Berlow, E., Bloomfield, J., Dirzo, R., Huber-Sanwald, E., Huenneke, L.F., Jackson, R.B., Kinzig, A. and Leemans, R., 2000. Global biodiversity scenarios for the year 2100. Science, 287(5459), pp.1770-1774.

Convention on Biological Diversity (CBD), 1992. United Nations 